\title{
INFLUENCE OF WATERBORNE CADMIUM ON THE GROWTH AND IMMUNE-PHYSIOLOGICAL PARAMETERS OF NILE TILAPIA (Oreochromis niloticus)
}

\author{
Safaa M. Sharaf \\ Department of Animal Production and Fish Resources, Faculty of Agriculture, Suez Canal \\ University, Ismailia 41522, Egypt, Corresponding author email: safaa_sharaf@agr.suez.edu.eg
}

\section{SUMMARY}

Nile tilapia, Oreochromis niloticus $(65.2 \pm 2.2 \mathrm{~g})$ were randomly distributed into 12 glass aquaria to represent 4 treatments (3 replicates per treatment). Fish were exposed to cadmium chloride at concentrations of 0.0 (control), 0.05 (T1), 0.10 (T2) and $0.15 \mathrm{mg} \mathrm{L}^{-1}$ (T3) for 4 weeks. After the first, third and fourth week, fish were immediately anesthetized and blood was collected. Fish weight was significantly affected by Cd exposure concentrations after the fourth week. Survival rate was decreased significantly with increasing Cd concentrations at the end of the experiment. The Cd accumulation was determined in fish gills, liver and muscles of Nile tilapia,; however, which these values increased significantly by increasing $C d$ concentrations and exposure period concentrations after the third and fourth week of exposure. One week after exposure, IgM titer was significantly increased with increasing cadmium concentrations, while after the third and fourth week of exposure, IgM was significantly decreased with increasing Cd concentrations. RBCs and Ht values were significantly decreased by increasing Cd concentrations where their highest values were obtained at control and the lowest ones were obtained at T3. The lowest values of $\mathrm{Hb}$ were recorded at T1. The MCV and MCHC values were insignificantly affected by $C d$ exposure, while MCH values were increased significantly with increasing Cd concentrations. Serum total protein and globulin were not significantly affected by increasing Cd concentrations for the whole period, while albumin was significantly affected at T3 after the first and fourth week of exposure. This study provides significant evidence that waterborne cadmium concentrations cause anemia and suppress immunity in exposed fish. It could be concluded that $C d$ toxicity induced deleterious effects on fish, which were reflected on growth rate, residual of Cd in different tissues, the concentration of blood IgM and haematological parameters. Moreover, immune suppression could play an important role in predisposing for further infections conditions.

Keywords: Oreochromis niloticus, Cadmium, growth, haematology, immune response

\section{INTRODUCTION}

Fish are particularly sensitive to water pollutants, which could impair many physiological and biochemical processes assimilated by fish tissue (Durmaz et al., 2006). The agricultural and industrial wastes, partially treated or without treatment are being discharged into surface water (Burger et al., 2007 and Forstner and Wittmann, 2007). Such metals are absorbed from polluted water through gills, skin, and digestive tract of fish by bio-concentration and bio-magnification. Heavy metals are persistent contaminants in the environment that come to the forefront of dangerous substances such as cadmium, lead, mercury, copper and zinc causing serious health hazards in humans and animals (Zaki et al. 2009). Moreover, heavy metals such as iron, copper, zinc, lead, cadmium, mercury, chromium and manganese when discharged into the water bodies can enter the food chain, bioaccumulate in fish and hence become a threat to a man (Ajmal et al., 1985). A comparative assessment of numerous heavy metals is an important in determining the degree of pollution in environmental systems.
However, interpretation of data sets comprising analyses of several metals is complicated (Bhuiyan et al., 2010).

Cadmium $(\mathrm{Cd})$ is a non-nutrient metal that can be found in the water and sediment as a result of anthropogenic activities such as mining and industrial processes (Baldisserotto et al., 2004). The concentration of this element in ambient waters varies between 0.1 to $10 \mathrm{mg} \mathrm{l}^{-1}$, while, in anthropogenically polluted waters, it can reach $50 \mathrm{mg} \mathrm{l}^{-1}$ (Linnik and Iskra, 1997) and induces C-reactive protein and metallothioneins (Paul and Mandal, 1998; De Smet et al., 2001). Although WHO (1989) reported that the permissible level of $\mathrm{Cd}$ in water and fish muscles are $0.01 \mathrm{ppm}$ and $1.0 \mathrm{mg} \mathrm{g}^{-1}$, respectively, fish can accumulate $\mathrm{Cd}$ to levels 10-1000 times higher than its level in ambient water. Low existence of cadmium in ambient water can produce significant accumulation of cadmium in fish muscles and its subsequent consumption by human may cause some pathophysiological disturbances in human body (Malekpouri et al., 2011).

This metal suppresses immune response to parasites (Thuvander, 1992). Exposure to $\mathrm{Cd}$ 
causes the most pronounced changes in the leucocytes ratio in peripheral blood of common carp compared to other metals in the order $\mathrm{Cd}>\mathrm{Pb}>\mathrm{Cu}>\mathrm{Hg}$, and neutrophils are the most sensitive type of blood cells (Serpunin and Korobeinikova, 1997). A study performed on Mozambique tilapia, Oreochromis mosambicus revealed not only neutrophilia but also thrombocytosis (Ruparelia et al., 1990). At the same time, exposure of rainbow trout, Salmo gairdneri to $\mathrm{Cd}$ did not reveal any changes in the leucocyte formula and in ration of phagocyte cells (Thuvander, 1989). The immune response can be modified by several stessors. Both defense mechanisms and non-specific activity may be affected (Anderson, 1990). However, sometimes pollutant stressors may enhance certain defense parameters, e.g. an increase in circulating antibodies in the serum of striped bass exposed to water with small amounts of cadmium (Robohm, 1986). The immune system is by many environmental pollutants, including heavy metals, even at low levels of exposure (Exon and Koller, 1986). Fish are often exposed to subtoxic concentrations of $\mathrm{Cd}$, which may affect the immune system, causing a modified immune response to infectious agents.

Nile tilapia, Oreochromis niloticus (L.) are native to Egypt and are worldwide distributed (El-Sayed, 2006). This species has been used previously in laboratory studies and has been shown to be a suitable organism for monitoring the effects of xenobiotics.

The goal of the present work is to study changes in immune-physiological parameters in the peripheral blood and immune-competent organs in response to sublethal waterborne $\mathrm{Cd}$ exposure. In addition, the study was set to answer the question of if the above mentioned parameters may be used for indication of the state of fish and the environment.

\section{MATERIALS AND METHODS}

\section{Fish:}

The present study was carried out at the wet Laboratory of the Animal Production and Fish Resources Department, Faculty of Agriculture, Suez Canal University, Ismailia, Egypt. Nile tilapia, Oreochromis niloticus were obtained from Central Laboratory for Aquaculture Research at Abbassa, Abou Hammad, Sharqia, Egypt and acclimated for 15 days before the beginning of the experiment for the normal laboratory conditions. Fish $(65.2 \pm 2.2 \mathrm{~g})$ were randomly distributed into 12 glass aquaria $(35 \times 40 \times 70 \mathrm{~cm})$ at a rate of 10 fish per each to represent 4 treatments (3 replicates per treatment). De-chlorinated tap water was used throughout the study. Fish were exposed to cadmium chloride at concentrations of 0.05 (T1), 0.10 (T2) and 0.15 $\mathrm{mg} \mathrm{Cd} \mathrm{L}{ }^{-1}$ (T3) for 4 weeks. Fish were fed the experimental diet at the rate of $3 \%$ of body weight per day, $30 \%$-crude protein diet up to satiation twice daily six days a week. Siphoning a half of aquarium's water was done every day for excreta removing and replaced by an equal volume of water containing the same $\mathrm{Cd}$ concentration.

\section{Physiological measurements:}

After the first, third and fourth week of $\mathrm{Cd}$ exposure, fish were immediately anesthetized with MS222 (30 mg l-1; Ethyl 3aminobenzoate methanesulfonate salt; Sigma), and blood was collected with a hypodermic syringe from the caudal vein. The extracted blood was divided in two sets of Eppendorf tubes. One set contained EDTA used as an anticoagulant, for haematology (haemoglobin and red blood cell counting). The second set, without anticoagulant, was left to clot at $4{ }^{\circ} \mathrm{C}$ and centrifuged at $5000 \mathrm{rpm}$ for $5 \mathrm{~min}$ at room temperature. The collected serum was stored at $-20{ }^{\circ} \mathrm{C}$ for further assays. Hemoglobin $(\mathrm{Hb} \mathrm{g}$ $\mathrm{dl}^{-1}$ ) level was determined colorimetrically by measuring the formation of cyanomethaemoglobin according to Handy et al. (1999). Haematocrit (Ht \%) was measured as packed cells volume (PCV \%) by using a micro haematocrit method. Red blood cells (RBCs x $10^{6} \% \mathrm{~cm}$ ) were counted under the light microscope using a Neubauer haemocytometer after blood dilution with phosphate-buffered saline ( $\mathrm{pH}$ 7.2). The red blood indices; mean corpuscular volume (MCV $\mu \mathrm{m}^{3}$ ), mean corpuscular haemoglobin ( $\mathrm{MCH}$ pg) and mean corpuscular haemoglobin concentration (MCHC $\mathrm{g} \mathrm{dl}^{-1}$ ) were calculated according to Brown (1980). Total protein, albumin, and globulin (Sundeman, 1964), were measured in blood serum by colorimetric methods using commercial kits.

\section{Measurement of serum immunoglobulin $M$ concentration:}

Total Immunoglobin $\mathrm{M} \quad(\mathrm{IgM})$ concentration in the serum was measured by enzyme-linked immunosorbent assay (ELISA) according to the method of Takemura (1993). Purified tilapia IgM, rabbit anti-tilapia $\operatorname{IgM}$ antibody (a-IgM) and a-IgM labeled with horseradish peroxidase (a-IgM HRP) was prepared in advance (Takemura, 1993). Each well of a 96-well microtiter plate (Becton Dickinson Labware, Franklin Lakes, NJ) was coated with $100 \mu \mathrm{l}$ of a-IgM $(6.8 \mu \mathrm{g} / \mathrm{ml})$ in $0.05 \mathrm{M}$ sodium carbonate buffer, $\mathrm{pH} 9.6$, and incubated for $2 \mathrm{~h}$ at $25{ }^{\circ} \mathrm{C}$. Residual protein binding sites were blocked by adding $200 \mu \mathrm{l}$ of $1 \%$ gelatin (BioRad Laboratories, Richmond, CA) dissolved in $10 \mathrm{mM}$ phosphate-buffered 
saline (PBS), pH 7.4, containing $0.05 \%$ Tween 20 (PBS-Tween) to the wells for $60 \mathrm{~min}$ at 25 ${ }^{\circ} \mathrm{C}$. After washing the wells three times with PBS-Tween using a plate washer (Immunowash 1573, BioRad), $100 \mu \mathrm{l}$ of plasma sample $(1: 10000)$ or standards (serial dilution of purified tilapia $\operatorname{IgM}$ ) was added to the well and then incubated overnight at $4{ }^{\circ} \mathrm{C}$. All the dilutions were made with PBS-Tween. After washing the wells three times with PBSTween, $100 \mu$ l of a-IgM HRP (diluted 1:20000 in PBS-Tween) was added to the wells and incubated for $2 \mathrm{~h}$ at $25{ }^{\circ} \mathrm{C}$. After three successive washes with PBS-Tween, peroxidase activity was measured by adding $100 \mu \mathrm{l}$ of $100 \mathrm{mM}$ citrate buffer, $\mathrm{pH} 4.5$, containing $\quad 0.01 \% \quad$ o-phenylenediamine dihydrochloride (Sigma, St. Louis, MO) and $0.04 \% \mathrm{H}_{2} \mathrm{O}_{2}$. Following 30-min incubation at $25{ }^{\circ} \mathrm{C}$, the enzymatic reaction was stopped by adding $25 \mu \mathrm{l}$ of $4 \mathrm{NH}_{2} \mathrm{SO}_{4}$. The optical density of each sample was determined at $490 \mathrm{~nm}$ using a microplate reader 550 (BioRad). Computer software (Microplate Manager III, version 1.57) was used for conversion from optical density to $\operatorname{IgM}$ concentration.

\section{Residual measurement:}

Residual heavy metal (Cd) was detected in gills, liver, and muscles according to APHA (1985). Fish tissues were ashed in a muffle furnace at $550^{\circ} \mathrm{C}$ for $6 \mathrm{~h}$, then $2 \mathrm{ml} \mathrm{HNO}_{3}$ was added and the sample was filtered to get a pure solution. After that, $\mathrm{Cd}$ was measured by using atomic absorption spectrophotometer (Syatem, 45AA, International Equipement Trading Ltd. Vernon Hills, Illinois, USA.

\section{Statistical analysis}

The data were statistically analyzed by completely randomize experiment (one-way ANOVA) according to the following Model 1: Yij $=\mu+$ Ti eij, where Yij $=$ an observation, $\mu$ $=$ the overall mean, $\mathrm{Ti}=$ the fixed effect of cadmium concentrations $(i=1, . .3)$, and eij $=$ random error. Statistical significance was set at the $5 \%$ probability level and means were determined by Duncan's New Multiple Range test (Duncan, 1955). The software SPSS, version 15 (SPSS, Richmond, USA) was used as described by Dytham (1999).

\section{RESULTS}

Fish weight (Table 1) was significantly affected by $\mathrm{Cd}$ exposure for 4 weeks. The lowest fish weight was obtained at T2 and T3 (73.3 and $72.8 \mathrm{~g}$, respectively). Survival rate decreased significantly $\quad(\mathrm{P}<0.05) \quad$ with increasing $\mathrm{Cd}$ concentrations after the fourth week of exposure. The $\mathrm{Cd}$ accumulation in fish gills, liver and muscles is shown in Table (2). Results showed that $\mathrm{Cd}$ accumulated in gills increased significantly by increasing $\mathrm{Cd}$ concentrations after the third and fourth week of exposure. The same results were obtained for $\mathrm{Cd}$ accumulated in liver and muscles.

This experiment studied the effects of various $\mathrm{Cd}$ concentrations on the total $\operatorname{IgM}$ (Figure 1) present in O. niloticus serum. One week after exposure, IgM titer was significantly increased with increasing $\mathrm{Cd}$ concentrations, while after the third and fourth week of exposure, IgM was significantly decreased with increasing $\mathrm{Cd}$ concentrations $(\mathrm{P}<0.05)$. RBCs and $\mathrm{Ht} \%$ were significantly affected by $\mathrm{Cd}$ exposure concentrations, the highest RBCs and Ht values (Figure 2) were obtained at control and significantly decreased with increasing $\mathrm{Cd}$ concentrations after the first, third and fourth week of exposure. Control recorded the highest $\mathrm{Hb}$ values, whereas the lowest values of $\mathrm{Hb}$ were recorded at T3 (4.44, 4.15 and $3.02 \mathrm{~g} \mathrm{dl}^{-1}$ ) after first, third and fourth week of exposure, respectively.

The MCV and MCHC values were insignificantly $(\mathrm{P}<0.05)$ affected with $\mathrm{Cd}$ exposure concentrations, while $\mathrm{MCH}$ values were increased significantly with increasing Cd concentrations especially after the $1^{\text {st }}$ and $3^{\text {rd }}$ week of exposure (Figure 3 ).

Serum total protein and globulin were not significantly affected by increasing $\mathrm{Cd}$ concentrations for the whole period, while albumin was significantly affected $(\mathrm{P}<0.05)$ at T3 after the first and fourth week of exposure (Table 3).

\section{DISCUSSION}

Concerning the weight gain of Nile tilapia exposed to $\mathrm{Cd}$ for 4 weeks, the obtained data revealed a significant decrease in body weight gain which it could be due to the reduction in food consumption and/or the decrease in gross food conversion rate which resulted in inhibition of growth as previously reported (Abbas, 1994 and Marie et al., 1994). There are significant increases in $\mathrm{Cd}$ residues in fish gills, liver and muscles due to $\mathrm{Cd}$ exposure if compared with control. The $\mathrm{Cd}$ contents in gills is a result that fish accumulate the heavy metals from the water primarily through the gills (Zaghloul, 1997) and its uptake could be controlled by the amount of water passing through the gills. This accumulation may also due to the binding of heavy metals to metallothionein (Pratap et al., 1989). The previous data showed that the highest $\mathrm{Cd}$ concentrations were found in liver. This may be attributed to the major role of liver in the detoxification and protection from heavy metals exposure, both by producing metallothioneins and by acting as a storage site 
for bound metals (Freeman et al., 1983 and Pratap et al., 1989). In the last position, muscles possessed low $\mathrm{Cd}$ concentrations at T3 after the first, third and fourth week of exposure. These results were in agreement with Zaghloul (1997). This means that, although Nile tilapia which is the most popular fish, lives under the previous experimental polluted conditions, yet it is still considered as a good edible fish and not harmful to man if only muscles are eaten.

The present study provides evidence of the effect of various $\mathrm{Cd}$ concentrations on the basal level of fish immunoglobuins were examined, in relation to the period of exposure. However, a significant decrease of $\operatorname{IgM}$ and total protein during the experimental period were observed due to Cd toxicity. Reduction of IgM level indicated that the cadmium chloride toxicity leads to suppression of immune system of exposed fish which become susceptible to any infective agents (Fuda et al., 1991). The serum IgM was determined to find out information about fish immune system which was previously investigated in different species by many authors, in the present work, the purified IgM was revealed a single perception against specific polyvalent antiserum to fish immunoglobulin, t has clearly been proved (Jones et al., 1971) that the effect of $\mathrm{Cd}$ on the immune system depends on concentrations and exposure period. The great reduction in circulating $\operatorname{IgM}$ titer after one week of exposure indicates that, initially, $\mathrm{Cd}$ seriously impairs the immune system of tilapia. However, the subsequent increase in IgM titer suggests that, after initial inhibition of immune functions, fish started to activate some protective or compensatory mechanism. This may be correlated to the capacity of lemphocytes to synthesize metallothioneins in response to Cd exposure (Harley et al., 1989).

Haematological parameters have been considered as important indicators of fish health (Chen et al., 2004, and Martins et al., 2004). Regarding to haematological profile of $\mathrm{Cd}$-exposed fish, $\mathrm{RBCs}, \mathrm{Hb}$, and $\mathrm{Ht}$ values decreased. Studies demonstrated that the reduction in the number of erythrocytes in the blood and in Ht may be signs of bacterial infection (McNulty et al., 2003, Benli and Yildiz 2004 and Shoemaker et al,. 2006). In contrast, the erythrocyte number of another fish species, Scyliorchinus canicula, was increased when the fish was exposed to $15 \mathrm{mg}$ $\mathrm{Cd}^{-1}$ for a period of 24-96 hours (Tort and Torres, 1988). While, O'Connor and Fromm (1975) reported a decrease in RBCs number and $\mathrm{Ht}$, due to hemolysis as a consequence of $\mathrm{Hg}$ toxicity. On the other hand, other authors (Benfey and Biron 2000; Affonso et al., 2002 and Sampaio et al., 2007) suggested that in experiment of toxicity a lowered Ht level could be related to the conditions of confinement or stress induced by the lack of food. The decrease in blood parameters is accompanied by an increase in MCV and $\mathrm{MCH}$ and stable MCHC which may be due to haemolytic action which led to fluid loss to the tissue with subsequent decrease in plasma volume (Swift, 1981 and Svoboda et al., 2001). Significant increases in the $\mathrm{Hb}$ value and the number of the Ht were found in Carassius auratus gibelio and they were attributed to the toxic effects of textile dyes (Al-Sabti, 2000). MCV levels increased in Nile tilapia after the $4^{\text {th }}$ week and $\mathrm{MCH}$ levels increased after the $3^{\text {rd }}$ week of $\mathrm{Cd}$ exposure. These results are in agreement with Ruperalia et al. (1990).

Total protein is a relevant parameter for evaluating the physiological status and condition of fish, and thus an important diagnostic aid (Svetina et al., 2002). This parameter was hardly stable in this study. An important function of serum protein is the maintenance of osmotic balance between the circulating blood and the tissue spaces (Heath, 1995). Therefore, serum protein levels can be used as a diagnostic tool and a valuable test for evaluating the general physiological state. The study revealed that all studied functional and immune-physiological parameters changed under $\mathrm{Cd}$ ions impact. However, the directions of these changes were different in blood and other organs. This reflects the contributions of each organ in hemopoiesis and their sensitivity to toxicant.

This study provides significant evidence that $\mathrm{Cd}$ concentration cause anemia and suppress immunity in exposed fish. It could be concluded that $\mathrm{Cd}$ toxicity induced deleterious effect on fish which were reflected on the concentration of blood IgM, haematological parameters, tissue $\mathrm{Cd}$ residual and growth rate of Nile tilapia. Moreover, immune suppression could play an important role in predisposing for further infections conditions.

\section{REFERENCES}

Abbas, H.H., 1994. Effect of lead on some physiological and biochemical aspects of Nile tilapia (Oreochromis niloticus). M. Sc. dissertation, Cairo Univ. Egypt.

Affonso, E.G., V.L.P. Polez, C.F. Corrêa, A.F. Mazon, M.R. Araújo, G. Moraes and F.T. Rantin, 2002. Blood parameters and metabolites in theteleost fish Colossoma macropomum exposed to sulfide or hypoxia. Comp. Biochem. Physiol. 133(C): 375-382. 
Al-Sabti, K., 2000. Chlorotriazine reactive azo red 120 textile dye induces micronuclei in fish: Ecotoxicol Environ Saf., 47:149-155.

APHA (American Public Health Association), 1985. Standard methods for the examination of water and wastewater. $16^{\text {th }}$ addition, American Public Health Association, Washington, D. C.

Ajmal, M., M.A. Khan, and A.A. Nomani, 1985. Distribution of heavy metals in plants and fish of the Yamuna river (India). Environ. Monit. Assess., 5:361-367.

Anderson D.P., 1990. Immunological indicators of environmental stress on immune protection and disease outbreaks, Am. Fish. Soc. Symp. 8: 38-50.

Baldisserotto, B., C. Kamunde, A. Matsuo and C.M. Wood, 2004. A protective effect of dietary calcium against acute waterborne cadmium uptake in rainbow trout. Aquat. Toxicol., 67: 57-73.

Benli, A.C.K. and H.Y. Yildiz, 2004. Blood parameters in Nile tilapia (Oreochromis niloticus L.) spontaneously infected with Edwardsiella tarda. Aquacult. Res. 35: 1388-1390.

Benfey, T.J. and M. Biron, 2000. Acute stress response in triploid rainbow trout (Oncorhynchus mykiss) and brook trout (Salvelinus fontinalis). Aquaculture, 184: 167-176.

Bhuiyan, M.A., M.A. Islam, S.B. Dampare, L. Parvez, and S. Suzuki, 2010. Evaluation of hazardous metal pollution in irrigation and drinking water systems in the vicinity of a coal mine area of northwestern Bangladesh. Journal of Hazardous Materials 197: 10651077.

Brown B.A., 1980. Haematology. Principles and procedure $\left(3^{\text {rd }}\right.$ ed) Lea and Fadiger, Philadelphia. 356pp

Burger, J., M. Gochfeld, C. Jeitner, S. Burke and T. Stamm, 2007. Metal levels in flathead sole (Hippoglossoides elassodon) and great sculpin (Myoxocephalus polyacanthocephalus) from Adak Island, Alaska: Potential risk to predators and fishermen. Environmental Research, 103: 62-69.

Chen, C.Y., G.A. Wooster and P.R. Bowser, 2004. Comparative blood chemistry and histopathology of tilapia infected with Vibrio vulnificus or Streptococcus iniae or exposed to carbon tetrachloride, gentamicin, or copper sulphate. Aquaculture. 239: 421-443.

De Smet, H., B. De Wachter, R. Lobinski and R. Blust, 2001. Dynamics of (Cd, Zn)Metallothioneins in Gills, Liver and Kidney of Common Carp Cyprinus carpio during Cadmium Exposure. Aquat. Toxicol. 52 (2), 269-281.
Durmaz, H.; Y. Sevgiler and N. Üner, 2006. Tissue-specific antioxidative and neurotoxic responses to diazinon in Oreochromis niloticus. Pest. Biochem. Physiol. 84: 215-226.

Duncan, D.B., 1955. Multiple rang and multiple F-test. Biometrics, 11: 1-42.

Dytham, C., 1999. Choosing and using statistics: a biologist's guide. Blackwell Science Ltd., London, UK.

El-Sayed, A.F.M., 2006. Tilapia Culture. CABI publishing, CABI International Willingford, Oxfordshire, United Kingdom.

Exon, J.H. and L.D. Koller, 1986. Immunotoxicity of cadmium. In Handbook of Experimental Pharmacology. Cadmium (E. C. Foulkes, ed.) pp. 339-350. Berlin Heidelberg: Springer-Verlag.

Forstner, N. and G.T.W. Wittmann, 2007. Metal pollution in the aquatic environment. Springer Verlag, Belin.

Fuda, H., K. Sayano, F. Yamaji and A. Haraj, 1991. Serum immunoglobulin M (IgM during early development of Maso salmon on corhyrchus masu. Comp. Biochem, Physiol., 99: A 637-643.

Freeman, H.C., G.B. Sangalang, J.F. Uthe, E.T. Garside and P. Daye, 1983. A histological examination and analysis for polychlorinated hydrocarbons in shore atlantic cod (Gadus morhua). Arch. Environ. Contam. Toxicol., (12): 627-632.

Handy, R.D., D.W. Sims, A. Giles, H.A. Campbell and M.M. Musonda, 1999. Metabolic trade-off between locomotion and detoxification for maintenance of blood chemistry and growth parameters by rainbow trout (Oncorhynchus mykiss) during chronic dietary exposure to copper. Aquat. Toxicol. 47: 23-41.

Harley, C.B.; C.R. Menon, R.A. Rachubinski and E. Nieboer, 1989. Metallothionein mRNA and protein induction by cadmium in peripheral-blood leucocytes. Biochemical Journal. 262: 873-879.

Heath, A.G., 1995. Water pollution and fish physiology. Boca Raton: CRC press, pp.141-170.

Jones, R.H.; R.L. Williams and A.M. Jones, 1971. Effects of heavy metal on the immune response. Preliminary findings for cadmium in rats. Proceedings of the Society for Experimental Biology and Medicine. 137, 1231-1236.

Linnik P.N. and I.V. Iskra, 1997. Cadmium in Surface Waters: Concentration, Forms of Location, and Toxic Effects. Gidrobiol. Zh. 33 (6): 72-87.

Malekpouri, P., A.A. Moshtaghie, R. Hosseini and E. Ebrahimi, 2011. Short and long term effects of waterborne cadmium on growth and its muscle accumulation in Common 
Carp fish (Cyprius carpio) an experimental study. Turkish Journal of Fisheries and Aquatic Sciences. 11: 587-593.

Martins M.L., F. Pilarsky, E.M. Onaka, D.T. Nomura, J. Fenerick, K. Ribeiro, D.M.Y. Miyazaki, M.P. Castro and E.B. Malheiros, 2004. Haematologia eresposta inflamatória aguda em Oreochromis niloticus (Osteichthyes: Cichlidae) submetida aos estímulos único e consecutivo de estresse de captura. Bolm Inst. Pesca, São Paulo, 30: 71-80.

Marie, M.A., A.M. Haggag and K. Zaghloul, 1994. Haematological responses induced by hypoxic underground water in common carp Cyprinus carpio and the Nile catfish; Clarias lazera. J. Egypt. Ger. Soc. Zool. 13(A): 275-319.

McNulty S.T., P.H. Klesius, C.A. Shoemaker and J.J. Evans, 2003. Haematological changes in Nile tilapia (Oreochromis niloticus) infected with Streptococcus iniae by nare inoculation. J. World Aquacult. Soc. 34: 418-422.

O'Connor, D.V. and P.O. Fromm, 1975. The effect of methyl mercury on gill metabolism and blood parameters of Rainbow trout. Bull. Environ. Contam. Toxicol., 13(4): 406-411.

Paul I. and C. Mandal, 1998. Effect of Environmental Pollutants on the CReactive Protein of a Freshwater Major Carp, Catla catla," Dev. Comp. Immunol. $22(5 / 6):$ 519-532

Pratap, H.B., R.A. Lock and S.E. Bonga, 1989. Effect of waterborne and dietary cadmium on plasma ions of the teleost Oreochromis mossambicus interrelation to water calcium levels. Arch. Environ. Contam. Toxicol., 18(4): 568-575.

Robohm R.A., 1986. Paradoxical effects of cadmium exposure an antibacterial antibody responses in two fish species: inhibition in cunners (Tautogolabrus adspersus) and enhancement in striped bass (Morone saxatilis), Vet. Immunol. Immunopathol. 12: 251-262.

Ruparelia, S.G., Y. Verma, S.R. Saiyed and U.M. Rawal, 1990. Effect of Cadmium on Blood of Tilapia, Oreochromis mosambicus (Peters), During Prolonged Exposure. Bull. Environment Contam. Tox., 45: 305-312.

Sampaio, F.G, C.L. Boijink, E.T. Eliane Tie Oba, L.R. Dos Santos, A.L. Kalinin and F.T. Rantin, 2007. Antioxidant defenses and biochemical changes in pacu (Piaractus mesopotamicus) in response to single and combined copper and hypoxia exposure. Comparative Biochemistry and Physiology, 147(C): 43-51.
Serpunin G.G. and E.G. Korobeinikova, 1997. Response of the Blood System of Carp (Cyprinus carpio L.) to the Effects of Heavy Metals, in Proceedings of the 1st Congress of Ichthyologists of Russia (NPO BIOS, Astrakhan, , pp. 237-238.

Shoemaker C.A., C. Lim, M. Yildirim-Aksoy, T.L. Welker and P. Klesius, 2006. Growth response and acquired resistance of Nile tilapia, Oreochromis niloticus (L.) that survived Streptococcus iniae infection. Aquacult. Res. 37: 1238-1245.

Sundeman, M.F., 1964. Studies of the serum proteins. Am. J. Clim. Path, 1-21.

Svetina, A., Z. Matasin, A. Tofant, M. Vucemilo and N. Fijan, 2002. Haematology and some blood chemical parameters of young carp till the age of three years. Acta Veterinaria Hungarica. 50: 429-467.

Svoboda, M., V. Luskova, J. Drasrichova and V. Ilabek, 2001. The Effect of diazinon on haematological indices of common carp (Cyprinus carpio L.). ACTA VET. BRNO., 70: 457-465.

Swift, D.J., 1981. A holding box system for physiological experiment on rainbow trout (Salom gairdneri Richardson) requiring rapid blood sampling. J. Fish Biol., 18: 309-319.

Takemura, A., 1993. Changes in an immunoglobulin M (IgM)-like protein during larval stages in tilapia Oreochromis mossambicus. Aquaculture 115: 233-241.

Thuvander, A., 1989. Cadmium Exposure of Rainbow Trout Salmo gairdneri Richardson: Effects on Immune Functions, J. Fish. Biol. 35 (4): 521-529.

Thuvander, A., 1992. The Immune System of Salmonid Fish: Establishment of Methods for Assessing Effects of Aquatic Pollutants on the Immune Response," Dissertation Abstr. Int. 52 (2): 02-16.

Tort, L. and P. Torres, 1988. The Effects of Sub lethal Concentrations of Cadmium on Haematological Parameters in the Dog fish. Scyliorhinus canicula. J. Fish Biol., 32: 277-282.

WHO (World Health Organization), 1989. Guide lines for drinking water quality. Vol. 1, Recommendations WHO, Geneva, p. 19. Zaki, M.S., M.O. Moustafa, O.M. Fawzi, M. Khafagy and F.S. Bayumi, 2009. Clinicopathological, biochemical and microbiological change on grey mullet exposed to cadmium chloride. AmericanEurasian J. Agric. \& Environ. Sci., 5 (1): 20-23,

Zaghloul, K.H., 1997. Studies on the effect of water pollution along different sites of the river Nile on the survival and reproduction of some fresh water fishes. Ph. D. dissertation, Cairo Univ. Egypt. 
Table 1. The growth parameters rate and survival (Mean \pm SE) of Nile tilapia exposed to different Cd concentrations for 4 weeks

\begin{tabular}{lcccc}
\hline Items & Initial weight $(\mathrm{g})$ & Final weight $(\mathrm{g})$ & Weight gain $(\mathrm{g})$ & Survival rate \% \\
\cline { 1 - 3 } Treatments $\left(\mathrm{mg} \mathrm{l}^{-1}\right)$ & & & & \\
\hline Control & $65.3 \pm 0.6$ & $78.4^{\mathrm{a}} \pm 1.2$ & $13.1^{\mathrm{a}} \pm 0.57$ & $98.3^{\mathrm{a}} \pm 1.6$ \\
0.05 (T1) & $66.2 \pm 0.7$ & $75.2^{\mathrm{a}} \pm 1.4$ & $9.0^{\mathrm{b}} \pm 0.25$ & $90.2^{\mathrm{b}} \pm 2.5$ \\
0.10 (T2) & $65.4 \pm 0.5$ & $73.3^{\mathrm{b}} \pm 1.2$ & $7.9^{\mathrm{b}} \pm 0.26$ & $86.1^{\mathrm{b}} \pm 2.4^{\mathrm{c}}$ \\
0.15 (T3) & $64.8 \pm 0.8$ & $72.8^{\mathrm{b}} \pm 1.4$ & $8.0^{\mathrm{b}} \pm 0.50$ & $85.4^{\mathrm{c}} \pm 2.6$ \\
\hline
\end{tabular}

Means in the same column having different letters are significantly different at $\mathrm{P}<0.05$.

Table 2. Changes of $\mathrm{Cd}$ residues in different organs (ug/g dry weight) (Mean $\pm \mathrm{SE})$ of Nile tilapia exposed to different $\mathrm{Cd}$ concentrations for different periods

\begin{tabular}{lccc}
\hline Items & Gills & Liver & Muscles \\
\cline { 1 - 2 } Treatments $\left(\mathrm{mg} \mathrm{l}^{-1}\right)$ & & & \\
\cline { 1 - 2 } $1^{\text {st }}$ week of exposure & & & \\
Control & $0.011^{\mathrm{d}} \pm 0.00$ & $0.18^{\mathrm{d}} \pm 0.02$ & $\mathrm{ND}^{*}$ \\
$0.05(\mathrm{~T} 1)$ & $0.148^{\mathrm{c}} \pm 0.003$ & $28.24^{\mathrm{c}} \pm 2.25$ & $0.212^{\mathrm{c}} \pm 0.009$ \\
$0.10(\mathrm{~T} 2)$ & $0.316^{\mathrm{b}} \pm 0.005$ & $34.21^{\mathrm{b}} \pm 2.12$ & $0.521^{\mathrm{b}} \pm 0.011$ \\
$0.15(\mathrm{~T} 3)$ & $3.219^{\mathrm{a}} \pm 0.015$ & $59.54^{\mathrm{a}} \pm 4.23$ & $0.719^{\mathrm{a}} \pm 0.019$ \\
$3^{\text {rd }}$ week of exposure & & & \\
Control & $0.013^{\mathrm{d}} \pm 0.002$ & $0.21^{\mathrm{d}} \pm 003$ & $\mathrm{ND}^{*}$ \\
$0.05(\mathrm{~T} 1)$ & $0.251^{\mathrm{c}} \pm 0.005$ & $40.31^{\mathrm{c}} \pm 2.22$ & $0.425^{\mathrm{c}} \pm 0.018$ \\
$0.10(\mathrm{~T} 2)$ & $0.486^{\mathrm{b}} \pm 0.009$ & $58.41^{\mathrm{b}} \pm 4.52$ & $0.931^{\mathrm{b}} \pm 0.035$ \\
$0.15(\mathrm{~T} 3)$ & $6.421^{\mathrm{a}} \pm 0.321$ & $92.41^{\mathrm{a}} \pm 5.95$ & $1.512^{\mathrm{a}} \pm 0.052$ \\
$4^{\text {th }}$ week of exposure & & & \\
Control & & $0.25^{\mathrm{d}} \pm 0.02$ & $\mathrm{ND}^{*}$ \\
$0.05(\mathrm{~T} 1)$ & $0.016^{\mathrm{d}} \pm 0.002$ & $65.22^{\mathrm{c}} \pm 6.23$ & $0.518^{\mathrm{c}} \pm 0.017$ \\
$0.10(\mathrm{~T} 2)$ & $0.341^{\mathrm{c}} \pm 0.009$ & $86.32^{\mathrm{b}} \pm 7.29$ & $1.212^{\mathrm{b}} \pm 0.042$ \\
$0.15(\mathrm{~T} 3)$ & $0.562^{\mathrm{b}} \pm 0.012$ & $112.21^{\mathrm{a}} \pm 9.53$ & $2.217^{\mathrm{a}} \pm 0.089$ \\
\hline
\end{tabular}

Means in the same column within each classification bearing different letters are significantly $(\mathrm{P}<0.05)$ different.

*ND: not detected

Table 3. Changes in serum protein, albumin, and globulin (Mean \pm SE) of Nile tilapia exposed to different $\mathrm{Cd}$ concentrations for different periods

\begin{tabular}{lccc}
\hline Items & Protein $\left(\mathrm{g} \mathrm{dl}^{-1}\right)$ & Albumin $\left(\mathrm{g} \mathrm{dl}^{-1}\right)$ & Globulin $\left(\mathrm{g} \mathrm{dl}^{-1}\right)$ \\
\cline { 1 - 1 } Treatments $\left(\mathrm{mg} \mathrm{l}^{-1}\right)$ & & & \\
$1^{\text {st }}$ week of exposure & & & \\
Control & $4.22 \pm 0.52$ & $1.15^{\mathrm{a}} \pm 0.11$ & $3.07 \pm 0.21$ \\
$0.05(\mathrm{~T} 1)$ & $4.12 \pm 0.32$ & $1.01^{\mathrm{a}} \pm 0.21$ & $3.11 \pm 0.23$ \\
0.10 (T2) & $4.01 \pm 0.41$ & $0.94^{\mathrm{a}} \pm 0.04$ & $3.07 \pm 0.24$ \\
0.15 (T3) & $3.91 \pm 0.25$ & $0.82^{\mathrm{b}} \pm 0.05$ & $3.09 \pm 0.31$ \\
$3^{\text {rd }}$ week of exposure & & & \\
Control & $4.13 \pm 0.32$ & $1.03 \pm 0.06$ & $3.10 \pm 0.24$ \\
0.05 (T1) & $4.03 \pm 0.29$ & $0.98 \pm 0.07$ & $3.05 \pm 0.27$ \\
0.10 (T2) & $3.92 \pm 0.31$ & $0.86 \pm 0.08$ & $3.06 \pm 0.31$ \\
0.15 (T3) & $3.82 \pm 0.27$ & $0.82 \pm 0.07$ & $3.00 \pm 0.22$ \\
$4^{\text {th }}$ week of exposure & & & \\
Control & $4.21 \pm 0.31$ & $1.11^{\mathrm{a}} \pm 0.21$ & $3.10 \pm 0.22$ \\
0.05 (T1) & $4.03 \pm 0.28$ & $0.92^{\mathrm{a}} \pm 0.06$ & $3.11 \pm 0.21$ \\
0.10 (T2) & $3.92 \pm 0.21$ & $0.81^{\mathrm{a}} \pm 0.05$ & $3.11 \pm 0.19$ \\
0.15 (T3) & $3.82 \pm 0.22$ & $0.74^{\mathrm{b}} \pm 0.04$ & $3.08 \pm 0.16$ \\
\hline
\end{tabular}

Means in the same column within each classification bearing different letters are significantly $(\mathrm{P}<0.05)$ different. 


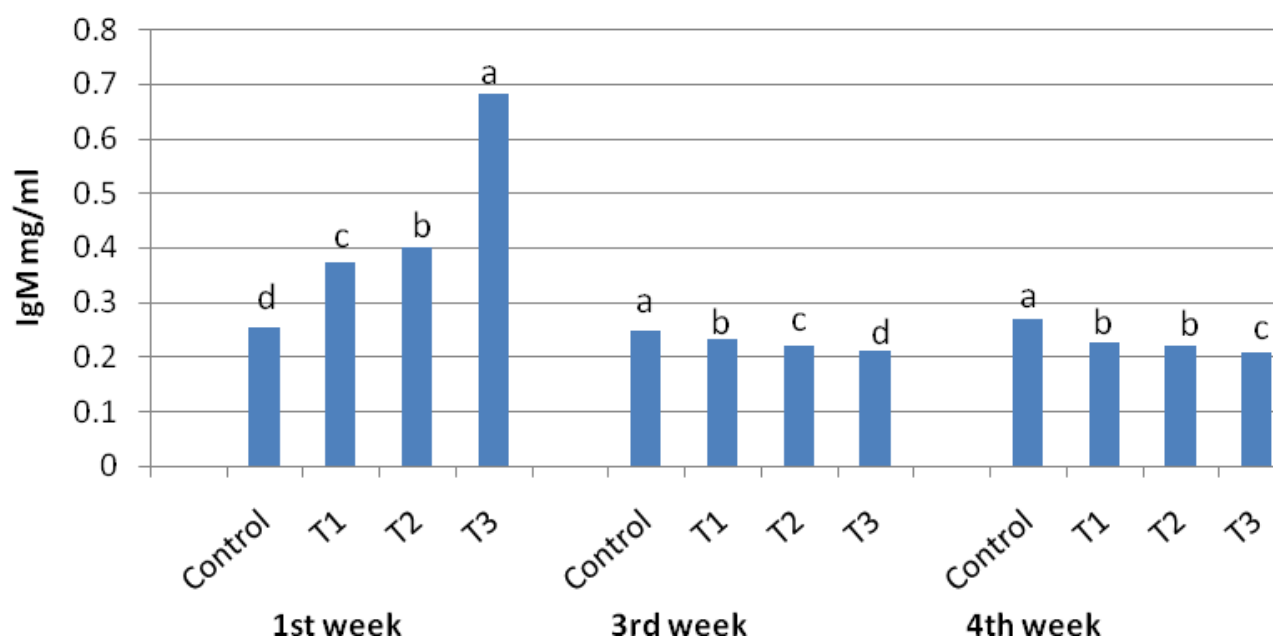

Figure 1. Changes in IgM $\left(\mathrm{mg} \mathrm{ml}^{-1}\right)$ in Nile tilapia exposed to different Cd concentrations for different periods.

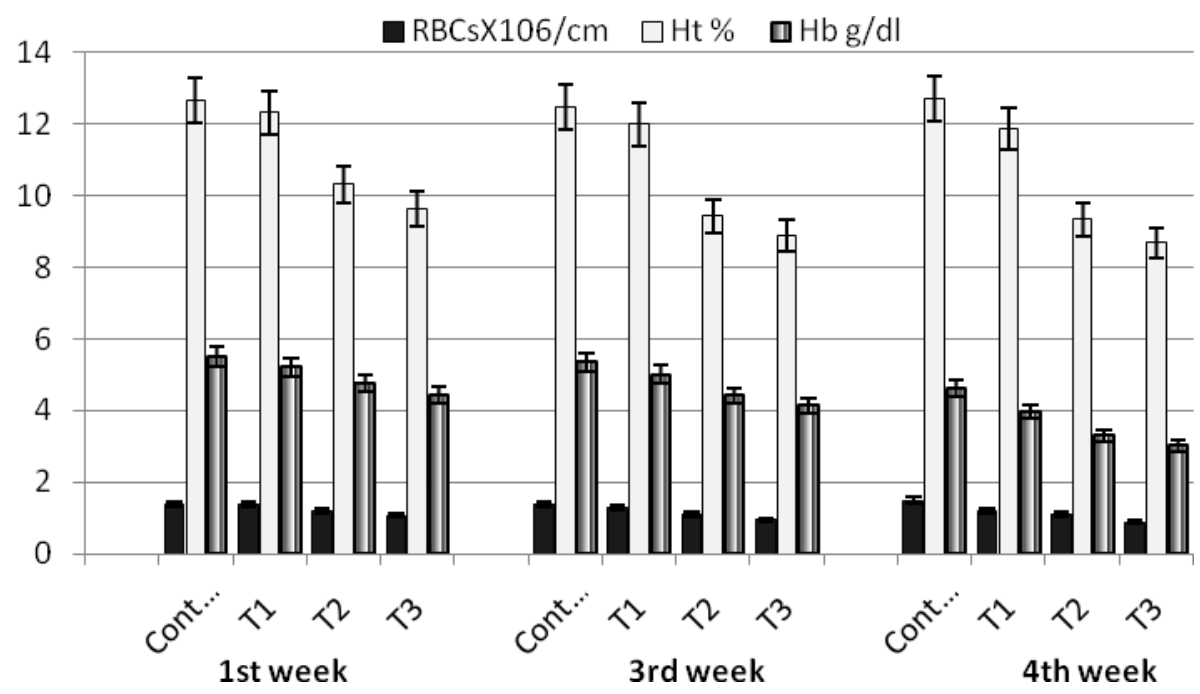

Figure 2. Changes in $\mathrm{RBCs}\left(\mathrm{x10}^{6} / \mathrm{cm}\right), \mathrm{Ht}(\%)$, and $\left.\mathrm{Hb}_{(\mathrm{g} \mathrm{dl}}{ }^{-1}\right)$ in Nile tilapia exposed to different Cd concentrations for different periods.

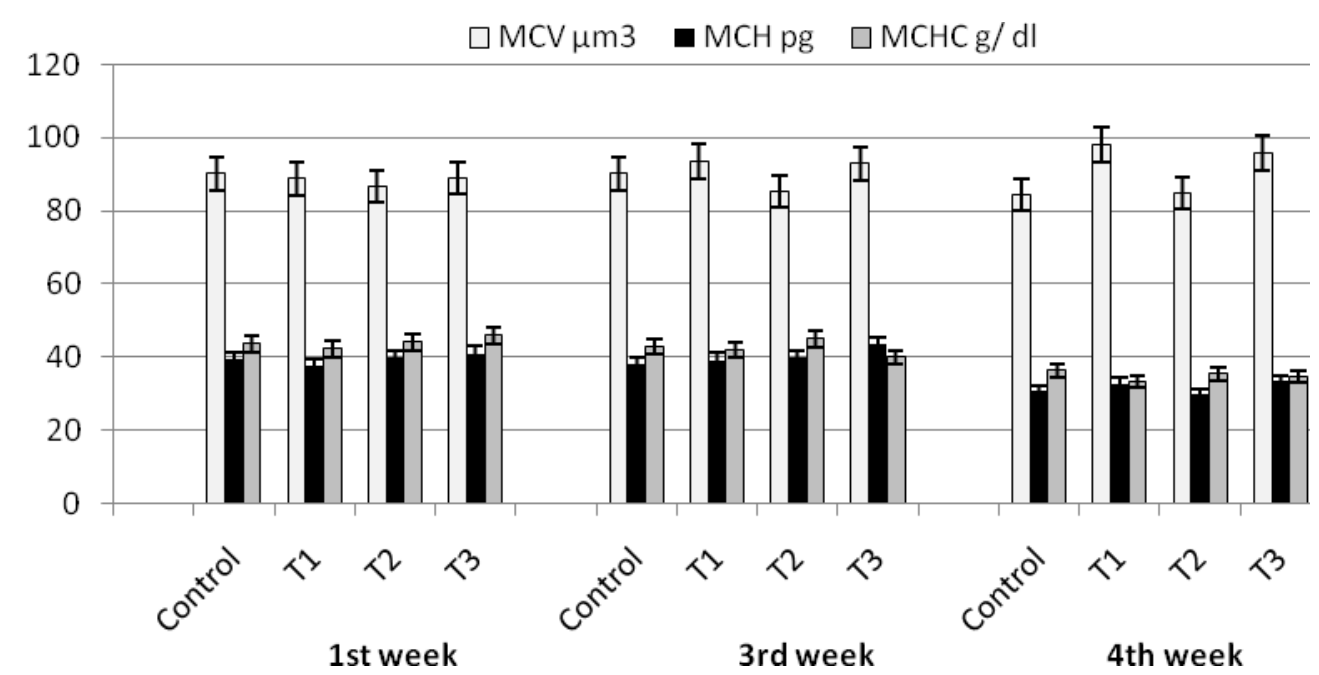

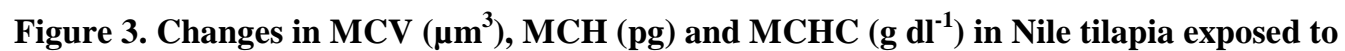
different $\mathrm{Cd}$ concentrations for different periods. 
تأثير الكادميوم المنقول عن طريق المياه على النمو و مدلولات المناعة الفسيولوجية للبلطي النيلي

صفاء محمود شرف

قسم الإنتاج الحيواني و الثروة السمكية ، كلية الزراعة، جامعة قناة السويس، الإسماعيلية ب ب ه ا ؛، مصر

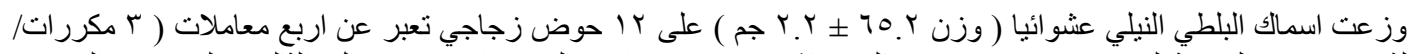

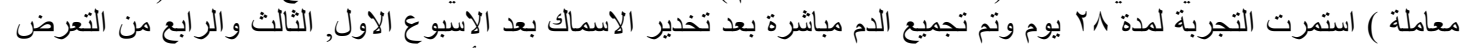

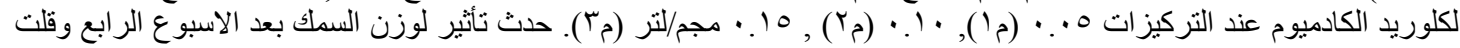

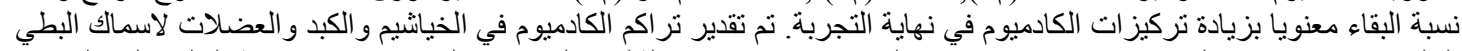

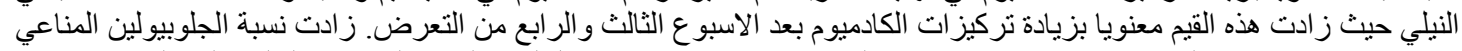

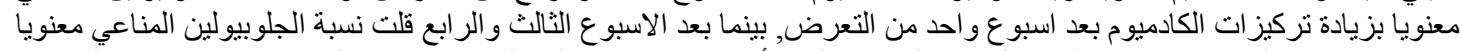

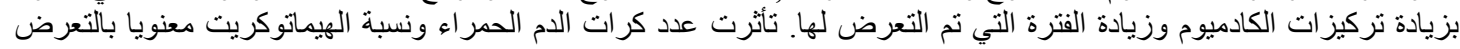

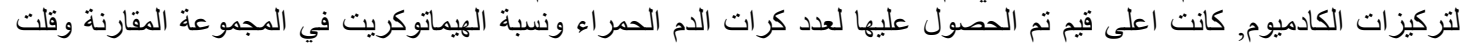

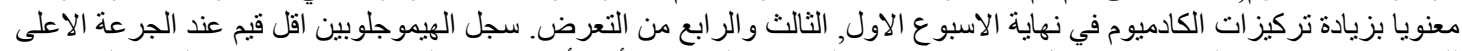

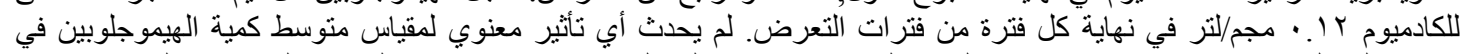

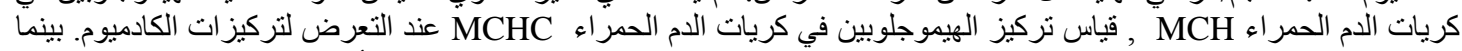

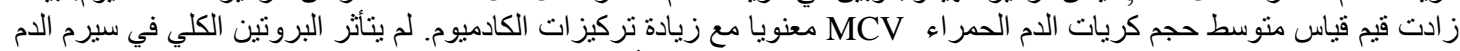

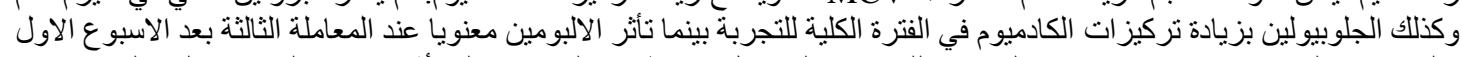

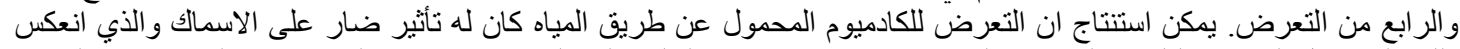

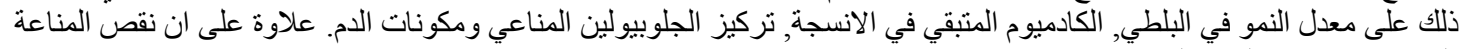
تلعب دور هام في التهيئة لمزيد من الالصابات. 